\title{
Pengaruh Implementasi Program “Temanku Sahabatku” dalam Meningkatkan Perilaku Prososial Anak Pra Sekolah
}

\author{
Evi Sri Restuwati ${ }^{1}$ dan Amitya Kumara ${ }^{2}$ \\ SMP IT Nurul Ilmi Cibarurusah. Perum Puri Persada Indah Blok AZ, Sindangmulya, Cibarusah, \\ Bekasi. \& Fakultas Psikologi Universitas Gadjah Mada Yogyakarta Jl. Sosio-Humaniora No. 1 \\ Bulaksumur, Yogyakarta evi.congming@yahoo.co.id / amikumara@yahoo.com
}

\begin{abstract}
Prosocial behavior made unique contributions to the prediction of educational achievement, sociability in the early years. Prosocial behavior was defined as acting that is either beneficial to or intended to benefit other people. Prosocial behavior could be expressed as helping, supporting, physical affection, or sharing. The "Temanku Sahabatku" program was adopted from a large themes from the book of The Anti-Bullying and Teasing Program for Preschool by Sprung, et al (2005), friendship theme. The "Temanku Sahabatku" program was the program which was designed as an effort to avoid bullying at school by improved children prosocial behavior. Teachers and students of two preschools in Sleman was going to involve in this study. This study was going to use quasiexperiment design, the untreated control group design with pre-test and post-test. Teachers were asked to implement the program which was trained before into first year preschoolers classroom in experiment group. The result of this study was the implementation of “Temanku Sahabatku” program was effective to improve the prosocial behavior of preschool children in experiment group rather than control group $(F=26,506 ; M D=-2,200 ; p<0,05)$.
\end{abstract}

Keywords: Program Anti-Bullying, friendship theme, prosocial behavior.

\begin{abstract}
ABSTRAK
Perilaku prososial diketahui memiliki kontribusi terhadap prediksi prestasi akademik dan kemampuan sosial di awal masa anak-anak. Perilaku prososial merupakan tindakan sukarela dengan niat untuk membantu orang lain yang dapat diekspresikan dalam bentuk perilaku membantu, mendukung, kasih sayang fisik, ataupun berbagi. Program “Temanku Sahabatku” merupakan adaptasi sebuah tema besar dari buku The Anti Bullying and Teasing Program for Preschool karya Sprung, dkk (2005), yaitu tema Persahabatan. Program “Temanku Sahabatku” merupakan program yang dirancang sebagai upaya pencegahan terhadap perilaku bullying dengan meningkatkan perilaku prososial anak. Guru dan siswa di dua Taman Kanak-kanak di Sleman, Yogyakarta akan dilibatkan dalam penelitian ini. Penelitian ini akan menggunakan desain eksperimen kuasi untreated control group design with pre-test and post-test. Guru diminta untuk mengimplementasikan program yang telah dilatihkan sebelumnya ke dalam proses belajar mengajar di kelas sebagai perlakuan pada siswa tahun pertama di TK kelompok eksperimen. Hasil penelitian ini adalah perilaku prososial anak prasekolah pada kelompok eksperimen yang diberikan perlakuan implementasi program
\end{abstract}


“Temanku Sahabatku” oleh guru meningkat secara signifikan daripada perilaku prososial anak prasekolah di kelompok kontrol $(F=26,506 ; M D=-2,200 ; p<0,05)$.

Kata kunci: Program Anti-Bullying, Tema Persahabatan, Perilaku Prososial.

\section{PENDAHULUAN}

Perilaku prososial diketahui memiliki kontribusi terhadap prediksi prestasi akademik dan kemampuan sosial di awal masa anak-anak, serta dapat menjadi prediktor yang signifikan dan reliabel untuk penyesuaian sosio-emosional anak selanjutnya (Chen, Liu, Rubin, dkk, 2002). Perilaku prososial merupakan tindakan sukarela dengan niat untuk membantu orang lain (Papalia, Old, \& Feldman, 2004). Menurut Eisenberg \& Mussen (1989), perilaku prososial adalah tindakan sukarela dengan maksud membantu dan memberikan manfaat kepada orang lain, yaitu berbagi (memberikan barang atau cerita), menolong (melakukan sesuatu untuk memudahkan pihak kedua), menunjukkan kasih sayang secara fisik agar pihak kedua merasa lebih nyaman dan tenang, memberikan dukungan (memberikan semangat atau kesempatan kepada orang lain), serta kerjasama.

1. Peneliti

2. Guru Besar Fakultas Psikologi Universitas Gadjah Mada

Eisenberg \& Mussen (1989) membagi perilaku prososial menjadi dua kategori, yaitu perilaku prososial spontan dan perilaku prososial berdasarkan permintaan. Kategori tersebut didasarkan pada motivasi yang mendasari munculnya perilaku prososial. Perilaku prososial spontan berhubungan dengan orientasi anak terhadap orang lain, penjelasan empati untuk keputusan moral, serta tingginya tingkat kemampuan untuk bersosialisasi dengan teman sebayanya. Misalnya ketika ada teman sebaya yang menangis, maka anak-anak berusaha menenangkan teman tersebut. Perilaku prososial yang kedua adalah perilaku prososial yang muncul berdasarkan permintaan teman sebaya. Misalnya, ada anak yang kehilangan pensil dan menanyakan kepada temannya, kemudian temannya mencarikan pensil tersebut.

Perilaku prososial dapat diajarkan kepada anak-anak sejak dini sebelum usia dua tahun, misalnya dengan membantu orang lain, berbagi kasih sayang dan makanan, serta menawarkan kenyamanan (Zahn-Waxler, Radke-Yellow, Wagner \& Chapman, dalam Papalia, Old, Feldman, 2004). Berdasarkan Milestone of Child Development (2008), anak-anak pada usia 4 tahun atau lebih mulai mempelajari untuk menunjukkan empati dan kepedulian terhadap orang lain, bekerjasama dengan orang lain, menunjukkan peningkatan kemampuan dalam memecahkan masalah, serta dengan mudah berinteraksi baik dengan anak-anak maupun orang dewasa. Dengan demikian, anak-anak usia 4 tahun atau lebih sudah mampu menunjukkan empati, kepedulian, dan kerjasama dengan teman sebayanya.

Hasil survei tahun 2012 terhadap 302 guru dari 79 Taman Kanak-kanak di Kabupaten Sleman menunjukkan bahwa 91\% guru menyatakan perilaku agresif di lingkungan siswa prasekolah masih banyak terjadi. Perilaku agresif verbal ditunjukkan dengan menertawai teman ditemukan sebanyak 83,44\%, mengatakan hal yang buruk pada teman $32,45 \%$ dan membungkam teman 13,25\%. Perilaku agresif yang dihubungkan dengan kepemilikan barang ditunjukkan dalam perilaku merebut barang milik teman ditemukan sebanyak 35,1\%, merusak barang teman $15,56 \%$, dan menyembunyikan barang milik teman 55,3\%. Agresi fisik juga 
terjadi seperti menarik rambut teman ditemukan sebanyak $28,4 \%$, memukul teman $74,17 \%$, menggigit teman $21,2 \%$ dan menendang teman $74,17 \%$. Begitu pula agresi secara psikologis misalnya, tidak mengizinkan teman untuk ikut bermain ditemukan sebanyak 65,23\% dan tidak memperbolehkan teman untuk duduk didekatnya 48,34\% (Hakim, Ismayasari, Pratistita, \& Restuwati, 2012). Data tersebut didukung pernyataan Stratton dan Reid (2004), yang menyatakan bahwa prevalensi masalah perilaku agresif anak prasekolah adalah sekitar 10\% hingga dapat mencapai 25\% pada anak-anak yang secara sosial-ekonomi kurang beruntung.

Anak yang agresif sering ditolak oleh teman-teman mereka, meskipun agresifitas tidak selalu menghalangi penerimaan teman sebaya. Resiko bagi anak-anak yang memiliki masalah emosi dan perilaku sejak dini diperparah dengan penolakan teman sebaya. Sebaliknya, persahabatan dan relasi yang positif sejak dini dengan teman sebaya dapat melindungi anak dari masalah-masalah psikologis ke depannya (Hay, 2005). Menurut Nelson dan Crick (dalam Damon, Lerner, \& Eisenberg, 2006), anak-anak yang menunjukkan perilaku agresif yang tinggi, cenderung menunjukkan rendahnya tingkat kemunculan perilaku prososial.

Pencegahan terhadap kekerasan dan agresivitas perlu untuk dilatihkan sejak dini, karena perilaku awal kekerasan dan agresivitas merupakan indikator munculnya masalahperilaku di masa yang akan datang (Hahn, dkk, 2007). Hasil penelitian Houbre, Tarquinio, Thuillier, dan Hergott (2006) menjelaskan bahwa masalah emosi, sosial, dan perilaku pada anak-anak memiliki dampak negatif, misalnya memicu timbulnya masalah akademis, masalah perilaku, emosi, sosial, dan psikosomatis, serta dampak negatif jangka panjang yang berkaitan dengan interaksi personal dan profesional setelah dewasa, sehingga dibutuhkan penanganan dini atas permasalahan-permasalahan tersebut.

Berdasarkan permasalahan tersebut, maka diperlukan suatu program yang diharapkan dapat meningkatkan perilaku prososial siswa prasekolah. Program tersebut adalah The AntiBullying and Teasing for Preschool Classroom (Sprung, 2005). Program ini merupakan suatu program yang menciptakan lingkungan yang saling menyayangi dan bersahabat. Cara yang ditempuh seperti dengan membuat aturan bersama, menjalankan aturan tersebut, serta belajar untuk memahami perasaaan diri sendiri dan orang lain. Program ini memiliki 4 tema besar yaitu komunitas, perasaan, persahabatan dan teasing and bullying.

Penelitian kali ini mengadaptasi tema persahabatan dan menuangkannya ke dalam program “Temanku Sahabatku”. Aktivitas dalam tema persahabatan ini mendukung anak-anak menyesuaikan diri di sekolah dan akan mengajarkan kepada anak-anak mengenai konsep empati, berbagi, bekerjasama dan bersahabat (Sprung, Froschl, dan Hinitz, 2005). Aktivitas ini memungkinkan anak-anak belajar tentang diri mereka sendiri dan menjalin persahabatan dengan lingkungan sosialnya. Dukungan persahabatan secara positif berhubungan dengan perilaku prososial, sedangkan konflik persahabatan secara positif berhubungan dengan tindakan agresif dan penolakan teman sebaya (Sebanc, 2003).

Teman sebaya dapat menyediakan persahabatan dan dukungan sebaik belajar berdasarkan pengalaman dalam bekerjasama dan bermain peran. Keluarga juga merupakan lingkungan sosialisasi anak yang memberikan dampak yang signifikan terhadap perkembangan anak. Begitu pula dengan sekolah, merupakan tempat dimana anak-anak secara formal belajar mengenai lingkungan sosial mereka. Para guru mendorong perkembangan berbagai macam keahlian dan perilaku dengan menjadi role model dan dengan memberikan motivasi bagi anak-anak untuk sukses dalam belajar (Berns, 2007).

Langkah nyata yang dapat membantu orangtua dan guru dalam meningkatkan perilaku 
prososial anak adalah dengan menciptakan situasi yang saling menyayangi dan hangat baik di sekolah maupun di rumah. Guru di sekolah dapat menjelaskan dan menjalankan aturan bagi anakanak, mendorong anak-anak untuk saling membantu, menghubungkan perilaku prososial ke dalam kualitas internal anak, serta memberikan contoh pemikiran positif dan perilaku dermawan (Ulutas \& Aksoy, 2009). Teman sebaya dan guru dapat menjadi model dan menguatkan perilaku prososial (Eisenberg \& Fabes, dalam Papalia, Old, \& Feldman, 2004).

Pada penelitian ini, guru diminta untuk mengimplementasikan program "Temanku Sahabatku” yang sebelumnya telah dilatihkan oleh Hakim (2013). Penelitian Hakim (2013) menunjukkan bahwa pelatihan program “Temanku Sahabatku” untuk menciptakan kelas bersahabat secara signifikan meningkatkan pengetahuan, pemahaman, dan performansi guru, sehingga guru-guru layak untuk mengimplementasikan program "Temanku Sahabatku” di kelas. Program tersebut berupa aktivitas-aktivitas kelas yang terdiri dari 4 teladan guru, 6 strategi kelas, 7 aktivitas tema komunitas, dan 8 aktivitas tema persahabatan.

Implementasi program yang dilakukan oleh guru memberikan pandangan bahwa siswa dapat menunjukkan perilaku prososial dapat digambarkan dengan menggunakan teori belajar sosial-kognitif. Teori sosial kognitif menggambarkan manusia sebagai makhluk yang unik, dinamis, serta belajar dengan melibatkan semua proses yang saling mempengaruhi antara kegiatan kognitif dalam memproses informasi, adanya motivasi kegiatan dari dalam diri, serta adanya stimulus dari luar. Manusia akan selalu mengembangkan proses belajarnya yang melibatkan proses kognitif serta standar penilaian perilaku oleh lingkungan. Salah satu bentuk proses belajar adalah observational learning, dimana di dalamnya terdapat modelling. Sebagian besar yang dipelajari manusia terjadi melalui peniruan atau imitation dan penyajian contoh atau modeling (Bandura, 1986). Proses berpikir dan belajar yang terjadi dalam modelling (Bandura, 1986) meliputi atensi, retensi, produksi, dan motivasi.

Teori sosial kognitif menjelaskan bahwa seseorang dapat belajar melalui modelling, yaitu meniru orang lain yang diamati, sehingga terdapat suatu bentuk perilaku untuk ditiru oleh seseorang untuk memulai terjadinya suatu proses belajar. Guru merupakan pemegang posisi sentral di sekolah sebagai model bagi siswa-siswa dalam melaksanakan aktivitas di sekolah. Seorang siswa dapat belajar mengubah perilakunya sendiri dengan menyaksikan orang atau sekelompok orang merespon sebuah stimulus tertentu. Siswa juga dapat mempelajari respon-respon baru dengan cara pengamatan terhadap perilaku contoh dari orang lain, misalnya guru atau orangtua.

Teori sosial kognitif juga menjelaskan bahwa anak akan dapat menginternalisasi aturan dengan cara meniru serta memahami penjelasan dari para socializer atau orang yang mensosialisasikan. Socializer ini memiliki peran penting bagi anak dalam mempelajari nilai-nilai serta perilaku. Salah satu socializer bagi anak adalah guru (Eisenberg \& Mussen, 1989). Pada penelitian ini guru mengimplementasikan guru tidak hanya memberikan contoh perilaku, akan tetapi juga mengajak anak untuk mendiskusikan hal-hal yang berhubungan dengan pertemanan, seperti bagaimana konsep pertemanan, berperilaku terhadap teman, aspek-aspek positif dan negatif dari suatu pertemanan, kosakata baru yang berhubungan dengan pertemanan, serta pentingnya kebaikan di kelas, sekolah, dan masyarakat. Setelah anak-anak memahami konsep pertemanan dan bagaimana memperlakukan teman, diharapkan perilaku prososial anak akan meningkat.

Hipotesis yang diajukan dalam penelitian ini adalah perilaku prososial anak prasekolah pada kelompok eksperimen yang diberikan perlakuan implementasi program "Temanku 
Sahabatku" oleh guru akan meningkat daripada perilaku prososial anak prasekolah di kelompok kontrol.

Penelitian ini bertujuan untuk melihat efektivitas implementasi Program "Temanku Sahabatku” oleh guru dalam meningkatkan perilaku prososial anak-anak prasekolah. Implikasi penelitian ini secara teoretis diharapkan dapat memberikan kontribusi pada keilmuan psikologi pendidikan. Sedangkan implikasi penelitian secara praktis diharapkan dapat menjadi salah satu alternatif pencegahan terjadinya bullying pada anak-anak.

\section{METODE PENELITIAN}

Subjek penelitian ini adalah siswa Taman Kanak-Kanak yang diampu oleh guru yang telah mendapatkan pelatihan program "Temanku Sahabatku”. Siswa Taman Kanak-Kanak ini berasal dari dua Taman Kanak-Kanak di Kabupaten Sleman, dimana TK pertama sebagai kelompok eksperimen perlakuan program “Temanku Sahabatku”, dan TK yang kedua sebagai kelompok kontrol. Subjek pada kelompok eksperimen berjumlah 25 anak, sedangkan pada kelompok kontrol berjumlah 24 anak. Subjek penelitian ini merupakan siswa prasekolah yang berusia 4-5 tahun.Pemilihan subjek berdasarkan usia tersebut didasarkan pernyataan dari Milestone of Child Development (2008), dimana anak-anak pada usia 4 tahun atau lebih mulai mempelajari untuk menunjukkan empati dan kepedulian terhadap orang lain, bekerjasama dengan orang lain, menunjukkan peningkatan kemampuan dalam memecahkan masalah, serta dengan mudah berinteraksi dengan satu atau lebih anak-anak dan orang dewasa.

Variabel tergantung pada penelitian ini adalah perilaku prososial. Perilaku

prososial merupakan tindakan sukarela untuk membantu dan memberikan manfaat kepada orang lain, meliputi berbagi (memberikan barang atau cerita), menolong (melakukan sesuatu untuk memudahkan pihak kedua), menunjukkan kasih sayang secara fisik agar pihak kedua merasa lebih nyaman dan tenang, memberikan dukungan (memberikan semangat atau kesempatan kepada orang lain), serta kerjasama (Eisenberg \& Mussen, 1989).

Manipulasi yang diberikan kepada kelompok eksperimen berupa implementasi program “Temanku Sahabatku” yang dilakukan oleh guru. Program tersebut diadaptasi dari tema Persahabatan dari bukuThe Anti-Bullying and Teasing Program for Preschool karya Sprung, dkk (2005). Hal yang dilakukan untuk menjaga supaya guru patuh dalam melaksanakan langkahlangkah implementasi adalah dengan melakukan monitoring dan melalui pengisian panduan observasi proses implementasi program Temanku Sahabatku.

Desain penelitian yang digunakan dalam penelitian ini adalah desain eksperimen kuasi, untreated control group design with pre-test and post-test (Shadish, Cook, Campbell, 2002). Desain ini memuat satu kelompok eksperimen dan satu kelompok kontrol, dimana kelompok eksperimen nantinya akan diberikan perlakuan berupa implementasi program "Temanku Sahabatku” oleh guru. Berikut adalah desain eksperimen kuasi dari penelitian ini:

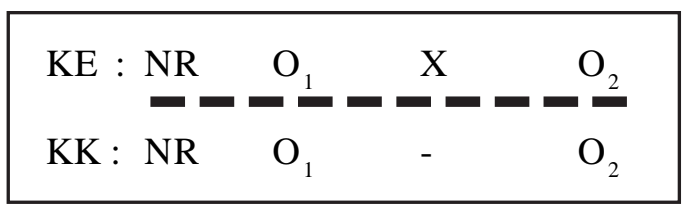

Gambar 1. Desain Eksperimen

\section{Keterangan:}

NR : Non Randomized

KE : Kelompok Eksperimen

KK : Kelompok Kontrol

$\mathrm{X}$ : Implementasi program "Temanku

Sahabatku” oleh guru

$\mathrm{O}_{1}$ : Pengukuran perilaku prososial siswa sebelum pemberian perlakuan 
implementasi program “Temanku Sahabatku"

$\mathrm{O}_{2}$ : Pengukuran perilaku prososial siswa setelah pemberian perlakuan perlakuan implementasi program “Temanku Sahabatku”

Perilaku Prososial dilihat dengan observasi. Panduan observasi yang digunakan adalah panduan observasi perilaku prososial yang disusun oleh Dara (2010). Panduan observasi tersebut disusun berdasarkan pengertian perilaku prososial dari Eisenberg dan Mussen (1989)yang meliputi:

1. Mendukung, misalnya memberikan semangat, memberikan pujian, serta memberi kesempatan untuk aktif kepada teman.

2. Kasih sayang fisik, misalnya memeluk, mengusap atau membelai anggota badan teman supaya teman merasa lebih tenang dan nyaman.

3. Berbagi, misalnya membagikan barang atau gagasan.

4. Kerjasama, misalnya membereskan mainan, menyusun balok, menempel, membuat poster aturan, dengan dua orang atau lebih.

5. Membantu/menolong, misalnya perilaku anak yang satu terhadap anak yang lain untuk memudahkan kedua belah pihak.

Observasi dilakukan dalam waktu satu minggu sebelum dan sesudah implementasi program. Observasi dilakukan oleh dua observer dengan durasi 30 menit setiap harinya. Observasi dilaksanakan pada saat pelajaran inti pada saat anak-anak sudah mulai beraktivitas bersama dengan teman-temannya di kelas. Perilaku prososial diobservasi kemunculannya di kelas melalui metode observasi dengan cara melakukan rating. Data yang diperoleh diolah dengan mencari angka kesepakatan atau konsistensi pencatatan informasi pengamatan untuk memperoleh reliabilitasnya.

Metode analisis data yang digunakan dalam penelitian ini adalah dengan menggunakan analisis varian campuran yang akan digunakan untuk menguji perbedaan skor antar kelompok yang dihasilkan dari data pretest dan posttest (Gravetter \& Wallnau, 2002), yaitu data yang berasal dari kelompok eksperimen, serta data dari kelompok kontrol.

\section{HASIL DAN PEMBAHASAN}

Uji hipotesis pada penelitian ini menggunakan teknik analisis data Anova mixed design dengan bantuan SPSS 15.0 for Windows dan diperoleh hasil sebagai berikut. Informasi statistik deskriptif menunjukkan padaTabel 1pretest diperoleh rerata skor perilaku prososial kelompok eksperimen sebesar 2,16 dengan deviasi standar 2,15 dan rerata skor perilaku prososial kelompok kontrol sebesar 2,87 dengan deviasi standar 3,21. Di sisi lain pada posttest didapatkan rerata skor perilaku prososial kelompok eksperimen 4,36 dengan deviasi standar 2,89 dan rerata skor perilaku prososial kelompok kontrol 1,08 dengan deviasi standar 1,28 . Hal ini menunjukkan bahwa skor perilaku prososial sebelum dan sesudah implementasi program “Temanku Sahabatku” pada kelompok eksperimen mengalami kenaikan. Sedangkan skor perilaku prososial pada kelompok kontrol mengalami penurunan.

Tabel 1. Statistik Deskriptif Perilaku Prososial Siswa pada Kelompok Eksperimen dan Kontrol

\begin{tabular}{ccccc}
\hline & Kelompok & Rerata & Deviasi Standar & $\mathbf{N}$ \\
\hline Pre & EKS & 2,1600 & 2,15407 & 25 \\
& KON & 2,8750 & 3,20750 & 24 \\
& Total & 2,5102 & 2,71663 & 49 \\
\multirow{2}{*}{ Post } & EKS & 4,3600 & 2,89943 & 25 \\
& KON & 1,0833 & 1,28255 & 24 \\
\hline & Total & 2,7551 & 2,78037 & 49 \\
\hline
\end{tabular}


Tabel 2. Ringkasan Uji Hipotesis Within-Subjects Perilaku Prososial Siswa

\begin{tabular}{clllllll}
\hline Source & & $\begin{array}{c}\text { Type III } \\
\text { Sum of } \\
\text { Squares }\end{array}$ & df & $\begin{array}{c}\text { Mean } \\
\text { Square }\end{array}$ & F & Sig. & $\begin{array}{c}\text { Partial } \\
\text { Eta } \\
\text { Squared }\end{array}$ \\
\hline Time*Group & Sphericity Assumed & 97,551 & 1 & 97,551 & 26,506 & 0,000 & 0,361 \\
& Greenhou se-Geisser & 97,551 & 1,000 & 97,551 & 26,506 & 0,000 & 0,361 \\
& Huynh-Feldt & 97,551 & 1,000 & 97,551 & 26,506 & 0,000 & 0,361 \\
& Lower-bound & 97,551 & 1,000 & 97,551 & 26,506 & 0,000 & 0,361 \\
\hline
\end{tabular}

Analisis uji hipotesis WithinSubjects(Tabel 2) perilaku prososial siswa menunjukkan interaksi perubahan skor perilaku prososial antara kelompok eksperimen dan kelompok kontrol. Hasil time* group pada baris Greenhouse-Geisser (Tabel 3) menunjukkan F= 26,506 ( $<<0,05)$, ini berarti terdapat perbedaan yang signifikan perubahan skor pre menuju post pada kedua kelompok (eksperimen dan kontrol). Interaksi atau perubahan skor pre menuju post tersebut menunjukkan bahwa peningkatan skor cukup tinggi terjadi pada kelompok eksperimen, sedangkan pada kelompok kontrol mengalami penurunan. pada kelompok kontrol selisih rerata pre dan post menunjukkan mengalami penurunan (MD= $1,792 ; \mathrm{p}<0,05)$. Nilai MD yang positif menunjukkan bahwa rerata posttest pada kelompok kontrol lebih rendah daripada rerata pretest, yang artinya siswa mengalami penurunan skor perilaku prososial. Hal tersebut menunjukkan bahwa perlakuan implementasi program “Temanku Sahabatku” yang diberikan oleh guru kepada siswa dapat meningkatkan perilaku prososial siswa.

Ringkasan sumbangan efektivitas implementasi program "Temanku Sahabatku” pada kolom Wilks’ Lambda menunjukkan

Tabel 3. Uji Lanjutan Selisih Rerata Perilaku Prososial Siswa

\begin{tabular}{lllrrrrr}
\hline & & & & & & \multicolumn{2}{c}{$\begin{array}{c}95 \% \text { Confidence Interval for } \\
\text { Difference(a) }\end{array}$} \\
\cline { 5 - 8 } TK & (I) time & $(\mathrm{J})$ time & $\begin{array}{c}\text { Mean } \\
\text { Difference (I-J) }\end{array}$ & Std. Error & Sig.(a) & $\begin{array}{c}\text { Upper } \\
\text { Bound }\end{array}$ & $\begin{array}{c}\text { Lower } \\
\text { Bound }\end{array}$ \\
\hline \multirow{2}{*}{ EKS } & 1 & 2 & $-2,200\left(^{*}\right)$ & 0,543 & 0,000 & $-3,292$ & $-1,108$ \\
& 2 & 1 & $2,200\left(^{*}\right)$ & 0,543 & 0,000 & 1,108 & 3,292 \\
KON & 1 & 2 & $1,792\left(^{*}\right)$ & 0,554 & 0,002 & 0,678 & 2,906 \\
& 2 & 1 & $-1,792\left(^{*}\right)$ & 0,554 & 0,002 & $-2,906$ & $-0,678$ \\
\hline
\end{tabular}

Uji selisih rerata perilaku prososial siswa (Tabel 3) menunjukkan bahwa perubahan perilaku prososial anak prasekolah pada kelompok eksperimen adalah signifikan (MD= $-2,200 ; \mathrm{p}<0,05$ ). Nilai selisih rerata (MD) yang negatif menunjukkan bahwa rerata posttest pada kelompok eksperimen lebih tinggi daripada rerata pretest, yang artinya siswa mengalami peningkatan skor perilaku prososial. Sedangkan
Partial Eta Squared sebesar 0, 259. Hal ini berarti bahwa implementasi program "Temanku Sahabatku” yang dilakukan oleh guru di kelas meningkatkan perilaku prososial anak sebesar $25,9 \%$.

Berdasarkan hasil analisis dengan menggunakan anava campuran ditemukan bahwa kondisi perilaku prososial kelompok kontrol menurun secara signifikan akibat adanya 
ancaman validitas internal berupa history (sejarah) yaitu adanya pergantian guru pada saat pengambilan data posttest perilaku prososial siswa, maka peneliti melakukan uji tambahan untuk mengukur kondisi perilaku prososial kelompok eksperimen tanpa dibandingkan dengan kelompok kontrol dengan menggunakan t-test. Hasil paired-sample t-test menunjukkan nilai $t$ sebesar -3,973 dan nilai $p$ sebesar 0,001 $(\mathrm{p}<0,05)$, artinya ada perbedaan signifikan antara skor perilaku prososial sebelum dan sesudah diberikan perlakuan implementasi program Temanku Sahabatku oleh guru. Selisih rerata skor perilaku prososial antara sebelum dan sesudah diberikan perlakuan sebesar -2,200, artinya skor perilaku prososial sesudah diberikan perlakuan mengalami peningkatan. mengimplementasikan program Temanku Sahabatku yang terdiri dari Empat Teladan Guru, yaitu Periksa, Ajak Main, Katakan, dan Berhenti; Enam Strategi Kelas, yaitu, Sudut "Tenangkan Diri”, Meja "Mari Kita Selesaikan”, Area Bermain Drama, Area Bermain Balok, dan Area Bermain Luar Ruangan; Tujuh Aktivitas Tema Komunitas; dan Delapan Aktivitas Tema Persahabatan. Sebelum mengimplementasikan program, guru diberikan pelatihan program Temanku Sahabatku dan telah terbukti mengalami peningkatan secara signifikan dalam hal pengetahuan, pemahaman, dan performansi (Hakim, 2013). Untuk memastikan bahwa guru mengimplementasikan program sesuai dengan modul yang dilatihkan sebelumnya, maka dilakukan monitoring menggunakan panduan

Tabel 4. Ringkasan Sumbangan Efektivitas Implementasi Program “Temanku Sahabatku

Dengan demikian, berdasarkan dua hasil analisis tersebut di atas, maka dapat disimpulkan bahwa implementasi program Temanku Sahabatku terbukti dapat meningkatkan skor perilaku prososial secara signifikan pada siswa kelompok eksperimen.

Hasil penelitian ini menunjukkan bahwa hipotesis penelitian terbukti, yaitu perilaku prososial anak prasekolah pada kelompok eksperimen yang diberikan perlakuan implementasi program "Temanku Sahabatku” oleh guru meningkat daripada perilaku prososial anak prasekolah di kelompok kontrol.

Langkah nyata yang dapat membantu guru dalam meningkatkan perilaku prososial anak adalah dengan menciptakan situasi yang saling menyayangi dan hangat di sekolah (Ulutas \& Aksoy, 2009). Untuk menciptakan situasi tersebut, guru-guru diminta untuk observasi proses implementasi program “Temanku Sahabatku”. Berdasarkan data hasil monitoring pelaksanaan implementasi program “Temanku Sahabatku” yang dilaksanakan guru dengan menggunakan panduan observasi pelaksanaan program diperoleh kesesuaian sebesar 81,2\%. Hal ini menunjukkan bahwa guru mengimplementasikan program "Temanku Sahabatku” sesuai dengan yang telah dilatihkan oleh peneliti sebelumnya.

Selama pelaksanaan implementasi, guru berperan sebagai socializer (Eisenberg \& Mussen, 1989), guru tidak hanya memberikan contoh perilaku, akan tetapi juga mengajak anak untuk mendiskusikan hal-hal yang berhubungan dengan pertemanan, seperti bagaimana konsep pertemanan, berperilaku terhadap teman, aspekaspek positif dan negatif dari suatu pertemanan, kosakata baru yang berhubungan dengan 
pertemanan, serta pentingnya kebaikan di kelas, sekolah, dan masyarakat. Selama implementasi program, selain berperan sebagai socializer, juga berperan sebagai model bagi siswa dalam melaksanakan aktivitas. Seorang siswa dapat belajar mengubah perilakunya sendiri dengan menyaksikan orang atau sekelompok orang merespon sebuah stimulus tertentu. Siswa juga dapat mempelajari respon-respon baru dengan cara pengamatan terhadap perilaku contoh dari orang lain (Bandura, 1986).

Teori sosial kognitif dapat menjelaskan mengenai proses siswa dalam mempelajari perilaku prososial. Seseorang dapat belajar melalui modelling, yaitu meniru orang lain yang diamati, sehingga terdapat suatu bentuk perilaku untuk ditiru oleh seseorang untuk memulai terjadinya suatu proses belajar. Proses berpikir dan belajar yang terjadi pada penelitian ini berdasarkan teori modelling (Bandura, 1986) adalah:

1. Atensi, yaitu tahap dimana seseorang memperhatikan atau mengamati orang yang dianggapnya lebih atau istimewa. Pada tahap ini siswa memperhatikan bagaimana guru menjelaskan dan memberikan contoh. Pada proses implementasi program, guru dapat menggunakan cerita, boneka tangan, ataupun roleplay dengan alat dan bahan yang menarik untuk menjelaskan materi, sehingga siswa tertarik untuk menyimak.

2. Retensi, yaitu tahap dimana informasi yang diperoleh kemudian disimpan di otak serta dapat disimbolkan secara imajinatif ataupun verbal untuk dapat digunakan sewaktuwaktu. Pada tahap ini kognitif siswa bekerja menyimpan dan mengingat aktivitas dan perilaku yang diajarkan dan dicontohkan oleh guru di kelas.

3. Produksi, yaitu tahap dimana seseorang menerjemahkan informasi yang diperoleh ke dalam perilaku. Pada tahap ini siswa akan menunjukkan perilaku sebagaimana yang dicontohkan oleh guru. Pada implementasi, guru akan mengajak siswa untuk mempraktikkan perilaku yang diajarkan, misalnya berbagi, memeluk, dan membantu temannya.

4. Motivasi, yaitu tahap dimana seseorang termotivasi untuk menunjukkan perilakuatau hasil belajar tertentu jika orang bersangkutan merasa akan mendapatkan keuntungan dari perilakunya tersebut. Implementasi pada tahap ini dilakukan dengan memberikan reward berupa pujian kepada anak yang dapat menerapkan atau meniru perilaku yang diajarkan, sehingga anak akan mengulang perilaku tersebut.

Siswa memperoleh berbagai macam bentuk perilaku dengan mengamati dan meniru orangtua, guru, teman, dan oranglain (Sundel\&Sundel, 2005). Perilaku prososial pada anak di sekolah sangat dipengaruhi oleh teman sebaya serta guru dan program sekolah (Eisenberg \& Mussen, 2003).

Guru diharapkan dapat senantiasa mendukung perkembangan perilaku prososial anak untuk memastikan bahwa anak-anak dapat menyesuaikan diri dan memiliki hubungan yang lebih baik dengan teman sebaya mereka. Guru di sekolah dapat menjelaskan dan menjalankan aturan bagi anak-anak, mendorong anak-anak untuk saling membantu, menghubungkan perilaku prososial ke dalam kualitas internal anak, serta memberikan contoh pemikiran positif dan perilaku dermawan (Ulutas \& Aksoy, 2009).

Penelitian ini selain melibatkan kelompok eksperimen yang diberikan perlakuan implementasi program Temanku Sahabatku oleh guru, juga melibatkan kelompok kontrol sebagai kelompok pembanding. Berdasarkan hasil penelitian diketahui bahwa skor perilaku prososial pada kelompok kontrol mengalami penurunan secara signifikan. Hal ini disebabkan adanya pergantian guru yang mengajar di kelas. Berdasarkan hasil wawancara dengan observer yang mengamati kelas tersebut, diketahui bahwa guru yang sebelumnya mengajar di kelas tersebut 
tidak bekerja lagi di sekolah tersebut dan digantikan oleh guru baru. Guru baru tersebut diketahui kurang mampu dalam mengkondisikan kelas, serta terkesan kaku dalam mengajar. Kondisi pergantian guru di sekolah kelompok kontrol dibenarkan oleh Kepala Sekolah. Berdasarkan wawancara dengan Kepala Sekolah pada tanggal 29 Januari 2013 diketahui bahwa guru baru yang mengajar di kelas A latar belakang pendidikannya bukan dari PGTK ataupun PAUD serta belum memiliki pengalaman mengajar di Taman Kanak-kanak. Kondisi yang terjadi pada kelompok kontrol ini tidak dapat dikontrol oleh peneliti, karena di awal penelitian pihak sekolah tidak mengemukakan adanya kemungkinan pergantian guru sebagaimana yang terjadi di pertengahan penelitian.

Peristiwa yang terjadi pada kelompok kontrol tersebut termasuk ke dalam ancaman terhadap validitas internal, yaitu sejarah (history). Menurut Shadish, Cook, dan Campbell (2002), sejarah (history)merupakan kejadian yang berlangsung pada saat bersamaan dengan perlakuan yang dapat menghasilkan efek yang teramati.

Keunggulan dari penelitian ini adalah penyajian aktivitas-aktivitas kelas yang kreatif dan menarik untuk siswa prasekolah, sehingga siswa antusias dalam mengikuti setiap implementasi aktivitas di kelas. Selain itu, aktivitas-aktivitas tersebut juga mudah untuk diterapkan oleh guru.

\section{SIMPULAN}

Kesimpulan dari penelitian ini adalah perilaku prososial anak prasekolah pada kelompok eksperimen meningkat secara signifikan setelah guru mengimplementasikan program “Temanku Sahabatku”. Meskipun demikian, perlu dicermati bahwa peningkatan skor perilaku prososial tersebut tidak hanya dipengaruhi oleh implementasi program, akan tetapi juga dipengaruhi oleh menurunnya skor prososial pada kelompok kontrol secara signifikan akibat munculnya ancaman terhadap validitas internal berupa history.Perilaku prososial anak prasekolah pada kelompok eksperimen tetap meningkat secara signifikan setelah guru mengimplementasikan program “Temanku Sahabatku”. Harapan peneliti Implementasi program "Temanku Sahabatku" diharapkan dapat terus diterapkan dan diintegrasikan dengan kegiatan pembelajaran di sekolah,. Penelitian selanjutnya diharapkan dapat melakukan pengukuran follow up supaya dapat melihat sejauh mana skor perilaku prososial siswa yang telah meningkat dapat bertahan setelah diberikannya implementasi program "Temanku Sahabatku” oleh guru. Peneliti selanjutnya diharapkan dapat menguji tema ke-empat, yaitu teasing and bullying.

\section{DAFTAR PUSTAKA}

Azwar, S. (2007). Dasar-Dasar Psikometri. Yogyakarta: Pustaka Pelajar.

Bandura, A. (1986). Social Foundations of Thought and Action: A Social Cognitive Theory. New Jersey: Prentice Hall, Inc.

Barboza, G.E., Schiamberg, L.B., Oehmke, J., Korzeniewski, S.J., Post, L.Al, Heraux, C.G. (2009). Individual Characteristics and the Multiple Contexts of Adolescent Bullying: An Ecological Perspective. J Youth Adolescence, 38: 101 - 121. Volume 38, Number 1 (2009), 101-121, DOI: 10.1007/s10964-008-9271-1.

Berns, R.M. (2007). Child, Family, School, Community : Socialization and Support 7th Edition. Canada : Thomson Learning, Inc.

Carlo, G. \& Randall, B.A. (2002). The 
Development of a Measure of Prosocial Behaviors for Late Adolescents.Journal of Youth and Adolescence, 31(1), 31-44. DOI: 10.1023/A:1014033032440.

Chen, X., Liu, M., Rubin, K.H., Cen, G., G, X., \& Li, D. (2002). Sociability and Prosocial Orientation as Predictors of Youth Adjustmen: a Seven-Year Longitudinal Study in a Chinese Sample. International Journal of Behavioral Development, 26(2), 128-136. DOI: 10.80/ 01650250042000690 .

Dara, Y.P. (2011). Pengaruh Impelementasi The Anti-Bullying and Teasing Program for Preschool Classroom Tema Komunitas oleh Guru dalam Meningkatkan Perilaku Prososial Anak Usia 4-5 Tahun di Kelas Taman Kanak-Kanak. Tesis. Yogyakarta : Fakultas Psikologi Universitas Gadjah Mada. Belum Diterbitkan.

Damon, W \& Eisenberg, N. (2006). Handbook of Child Psychology: Vol.3. Social, Emotional and Personality Development (5th ed., pp. 701-778). New York: John Willey.

Eisenberg,N. \& Fabes, R.A. (1989). Prosocial Development. In W. Damon (Series Ed.) and N. Eisenberg (Ed.), Handbook of Child Psychology: Vol.3. Social, Emotional and Personality Development (5th ed., pp. 701-778). Newyork: John Willey.

Eisenberg, N. \& Mussen, P. H. (1989). The Roots of Prosocial Behavior in Children. NewYork: Cambridge University Press.

Febriyanti, D.A.(2011). Pengaruh Implementasi
Program Menciptakan Kelas Bersahabat oleh Guru dalam Menurunkan Agresivitas di Kelas Taman Kanak-Kanak. Tesis. Yogyakarta : Fakultas Psikologi Universitas Gadjah Mada.Belum Diterbitkan.

Gravetter, F. J. \& Wallnau, L. B. (2002). Essentials of Statistics for the Behavioral Sciences $4^{\text {th }}$ Edition. Canada: Wadsworth.

Hahn, R., Whitley, D.F., Wethington, H., Lowy, J., Crosby, A., Fullilove, M., ..., \& Dahlberg, L. (2007). Effectiveness of Universal School-Based Programs to Prevent Violent and Aggressive Behavior: A Systematic Review.American Journal of Preventive Medicine, 33 (2S), 114129

Hakim, Z. A. (2013). Pelatihan Program “Temanku Sahabatku” dan Penerapan Strategi Serta Teladan Guru dalam Membentuk Kelas yang Bersahabat. Tesis. Yogyakarta : Fakultas Psikologi Universitas Gadjah Mada.Belum Diterbitkan.

Hay, D. F. (2005). Early Peer Relations and Their Impact on Children's Development. Encyclopedia on Early Childhood Development. Wales: Center od Excellence for Early Childhood Development.

Honig, A.S. (2009). Understanding and Working with Non-Compliant and Aggressive Young Children.Journal of Early Child Development and Care, 179(8), 1007-1023.

Houbre, B., Tarquinio, C., Thuillier, I., \& Hergott, E. (2006). Bullying Among 
Students and Its Consequences on Health.European Journal of Psychology of Education, 21(2), 183-208.

Irwin, D. M. \& Bushnell, M. M. (1980). Observational Strategies for Child Study. New York: Holt, Rinerhart, and Winston.

Jennings, P. A. \& Greenberg, M. T. (2009). The Prosocial Classroom: Teacher Social and Emotional Competence in Relation to Student and Classroom Outcomes. Journal of Review of Educational Research, 79(1), 491-525.41

Keanne, S.P. \& Calkins, S.D. (2004). Predicting Kindergarten Peer Social Status from Toddler and Preschool Problem Behavior. Journal of Abnormal Child Psychology, 32(4), 409-423.

Knafo, A. \& Plomin, R. (2006). Parental Discipline and Affection and Children's Prosocial Behavior: Genetic and Environmental Links. Journal of Personality and Social Psychology, 90(1), 147-164.

Knafo, A., Israel, S., \& Ebstein, R.P. (2011). Heritability of Children's Prosocial Behavior and Differential Susceptibility to Parenting by Variation in the Dopamine Receptor D4 Gene.Journal of Development and Psychopathology, 23,53-67.

Kumara, A., Dinardinata, A., Winahyu, G.P, Dara, Y.P. (2010). Efektivitas Program The Anti Bullying and Teasing Program for Preschool Classroom Dalam Meningkatkan Kualitas Iklim Kelas di Taman Kanak-Kanak. Naskah Publikasi (in process).

Kumara, A., Febriyanti, D.A., Sari, B.N., Sari,
H.I.P. (2011). Program Kelas Bersahabat dan Pengelolaan Kelas. Naskah Publikasi. Tidak Diterbitkan. Fakultas Psikologi Universitas Gadjah Mada Yogyakarta.

LeBreton, J. M. \& Senter, J. L. (2008). Answers to 20 Questions about Interrater Reliability and Interrater Agreement.Journal of Organizational Research Methods, 11(4), 815-852.

Office of Early Childhood Development Virginia Department of Social Services. (2008). Milestones of Child Development A Guide to Young Children's Learning and Development from Birth to Kindergarten Virginia's Early Childhood Development Alignment Project.

Papalia, D. E, Olds, S. W, Feldman, R. D. (2004). Human Development Ninth Edition. New York:McGraw Hill.

Persson, G. E. B. (2005). Developmental Perspective on Prosocial and Aggressive Motives in Preschoolers' Peer Interaction.International Journal of Behavioral Development, 29(1), 80-91. DOI: 10.1080/016502504440004231

Persson, G. E. B. (2005). Young Children's Prosocial and Aggressive Behaviors and Their Experiences of Being Targeted for Similar Behavior by Peers. Social Development, 14, 2.

Ramaswamy, V dan Bergin, C. (2009). Do reinforcement and induction increase prosocial behavior? results of a teacher-based interventions in preschools.Journal of Research in 
Childhood Education; Summer 2009; 23, 4; ProQuest Research Library pg. 527.

Rushton, J. P. (2004). Genetic and Environmental Contributions to Pro-Social Attitude: A Twin Study of Social Responsibility.The Royal Society Journal, 271, 2583-2583.

Sari, B.N. (2011).Pengaruh Pelatihan Program Menciptakan Kelas Bersahabat dalam Meningkatkan Kompetensi Guru Menciptakan Kelas yang Aman dan Nyaman Bagi Siswa Taman KanakKanak. Tesis. Yogyakarta : Fakultas Psikologi Universitas Gadjah Mada. Belum Diterbitkan.

Sari, H.I.P. (2011). Pengaruh Implementasi Program "Menciptakan Kelas Bersahabat” dalam Peningkatan Perilaku Prososial pada Siswa Taman Kanak-Kanak. Tesis. Yogyakarta : Fakultas Psikologi Universitas Gadjah Mada. Belum Diterbitkan.

Santrock, J. W. (2002). Life-Span Development: Perkembangan Masa Hidup, Edisi 5, Jilid 1. Jakarta: Erlangga.

Sebanc, A.M. (2003). The Friendship Features of Preescool Children: Links with Prosocial behavior and Aggression. Social Development, 12 (20, 245268.

Shadish, W.R., Cook, T.D., \& Campbell, D.T. (2002). Experimental and QuasiExperimental Design for Generalized Causal Inference. Boston: Houghton Mifflin Company.

Smith, P. K \& Hart, C.H. (2011). The WileyBlackwell Handbook of Childhood
Social Development. NY: Blackwell Publishers.

Sprung, B., Froschl, M., \& Hinitz, B. (2005). The Anti-Bullying and Teasing Book for Preschool Classrooms. Beltsville: Gryphon House, Inc.

Stratton, W. C., \& Reid, M. J. (2004). Strengthening Social and Emotional Competence In Young Children - The Foundation For Early School Readiness And Success: Incredible Years Classroom Social Skills And Problem-Solving Curriculum.Journal of Infants and Young Children, 17(2), 96-113.

Steedly, K.M., Schwartz, A., Levin, M., Luke, S.D. (2008). Social Skills and Academic Achievement.Evidence for Education Journal, 3(2).

Sundel, M., Sundel, S. S. (2005). Behavior Change in The Human Services: Behavioral and Cognitive Principles and Applications, Fifth Edition. London: Sage Publication.

Twenge, J.M., Ciarocco, N.J., Baumeister, R.F., DeWall, C.N., \& Bartels, J.M. (2007). Social Exclusion Decreases Prosocial Behavior.Journal of Personality and Social Psychology, 92(1), 56-66.

Ulutas, I. \& Aksoy,A. (2009). Learning with Play: How Play Activities Program Improve Pro-Social Behaviour of Six Year Old Children? Humanity and Social Sciences Journal, 49(1), 39-44.

Zimmer-Gembeck, M.J., Geiger, T.C., \& Crick, N.R. (2005). Relational and Physical Aggression, Prosocial Behavior, Peer Relations. Journal of Early Adolescence,25(4), 421-452.23 